\title{
UNDERSTANDING JUCHE IDEOLOGY THROUGH PSYCHOLOGY OF PEACE AND CONFLICT IN NORTH KOREA
}

\author{
Mega Nisfa Makhroja \\ Collegium Civitas \\ Email: $\underline{\text { meganisfa@gmail.com }}$
}

\begin{abstract}
This paper examined moral justification due to Juche's ideology in North Korea as the main reason for the survival of the authoritarian regime and caused violence. By using Moral Justification analysist from Psychology of peace and conflict, this paper explain how Juche Ideology affected to Violence, How intervention toward north Korean Conflict from international society, and possible scenario to implemented in North Korea. However, North Korean conflict not only affected their national issue, but also international level. High number of Human Right Violation in this country can be understood by psychological of peace and conflict studies.
\end{abstract}

Key words : Moral Justification, Juche, Psychology of Peace and Conflict, North Korea.

\section{INTRODUCTION}

Juche Ideology in Democratic People of Republic Korea or North Korea is the doctrine of self- reliance. Juche's idea meant that the masters of revolution and construction were the masses of the people and that they were also the driving force of the revolution and construction (Korea-DPR, n.d). Kim Il Sung, North Korean Leader since 1948, envisioned three specific applications of Juche philosophy: political and ideological independence, especially from the Soviet Union and China; economic self-reliance and self-sufficiency and viable national defense system (Grace Lee, 2003 pg 105). When this idea was implemented in the state philosophy, this doctrine wanted to emphasize that North Korea wanted to be independent in its own way, manage its own economy and society. Although in some aspects, poverty and hunger problems occurred but they were proud of the ideology held. Basically, this idea is the development of Stalin's teachings about communism, but then makes the values of autarchy important to control the power of communist leaders.

The human rights conditions in North Korea based on the United Nations Commission of Inquiry (UN-COI) show that many human rights violations are excluded by the Kim Jong Un regime in all forms including but not limited to restrictions on freedom of expression, press freedom, free trade unions and organized political opposition(Humanitarian Vision, 2018). The Juche doctrine strengthens military capacity in order to gain international recognition with its nuclear weapons. North Korea plays psychological warfare to attract international sympathy with its nuclear power. All form inline with their aims to get more aid 
and humanitarian assistance. However, national security is set aside. These problems face a chronic famine, the lack of adequate education and health facilities for North Korean.

In 2019, North Korea put 159 positions in the global peace index as a very low peace country (Institute of Economic and Peace, 2019). This position showed how cruel conditions in North Korea today and there is no improvement of peace since last year. This instability in North Korea has caused many North Koreans to defect. they face high frustration amidst the pressure of the Juche doctrine. Many of them fled to South Korea to Europe. However, the dilemmatic condition is again faced because they do not get certainty or guarantee of life at their destination.

According to Bandura, the Juche's implementation in North Korea can categorize as Moral Justification. It means, people can act on moral imperative and preserve their view of themselves as a moral agent while inflicting harm on others (Bandura, n.d.).The Juche, itself, as justification from the Communist regime in North Korea, clarified that what they did are right. Nuclear weapon development and highly country intervention are part of the country's self-reliance from another hegemon in the world. That's why the military budget is the main important than food or other infrastructure budgets.

Interesting that, juche ideology is product of psycology of peace and conflict from the authoritarian regime in North Korea that affected to humanitarian issue in those country. Moral disengagement in Juche Ideology affected their policy toward their society and other countries. They denied the number of violence and stand by their own perspective as good way. Then, the research question will focus on "How Juche Ideology affected violence from psychology of peace and conflict perspective?".

\section{ANALYSIS FRAMEWORK}

\section{Understanding Violence and Moral Disengagement Theory}

Who is Violence?

Before we figure out about moral disengagement in North Korea, it is important to understand, what kind of violence affected by Moral Disengagement in North Korea. Human right crisis in North Korea is one of the biggest humanitarian issues in the world. The violence that occurred in North Korea through the Juche ideology caused casualties at various levels. There are several forms of violence carried out, namely: a) direct violence, they are who against defectors and political opponents of the Kim family. They are put in prison and do not get certainty of life; b) structural violence, all people in North Korea have not the right 
to live as they want. They also can be categorize in cultural violence because the lack of access to education, health, and food is very worrying. Even the right to watching to Hollywood movies.

The people of North Korea feel imprisoned and very eager to get out of their country. However, they have no place. Although they managed to run, they did not get certainty. Psychologically, the people of North Korea experience a high level of frustration. Many people in North Korea try to escape from this country because of such a cruel condition. They have to walk hundreds kilometers to go through China or Mongolia. Some of them who decided to defector, realize that they do not have any opportunity in the life as a human, because they are only the God slaves. It seems that Juche ideology brained their wash to be obedient to the regime. People have doctrine that the leader of the country is God. They believe they live in the center of the universe. All of the people in North Korea are the servant for God (Leader) (Park, 2019).

In addition, problem in north Korea also has indirect impact on International community. The international community is also indirectly a victim of the North Korean antagonist policy, spread fears to the world. Therefore, several countries are trying to resolve this problem well.

During more than 60 years of the Kim Family regime established in North Korea, political control over power continues to be carried out starting from civil liberties, politics, expression, the media and all forms of organized opposition. The human rights watch report in 2019 continues to place North Korea as one of the most repressive countries in the world (Human Rights Watch: 2019). Pyongyang has pursued continuous integrated psychological warfare in all aspects of political, economic, social and military affairs at both tactical and strategic levels (Rouse, 2019). Kim's leader uses any kind of authoritarian power to control this nation-state and achieve his legitimate as one of the strong power (military) in the world.

Since 1953, the first time established, this regime believe their own ideology to achieve national goals, Juche. Authoritarian regime under Juche can inflict harm and yet justify that behavior to themselves as they believe they are acting in line with their moral standards (Jackson and Sparr, 2005). Juche ideology is deeply rooted in Korean society. Even this believe was erasing moral standards to achieve the goals of the state (government). Then, understanding inhuman action by North Korean government, what victim and how they affected can describe by moral disengagement theory.

\section{Moral Disengagement Theory}


Moral disengagement is psychology theory that explain by bandura in 1986. This theory explain about how individual can do harm to other even they do not want to do. The disengagement of moral self-sanctions from inhumane conduct is a growing human problem at both individual and collective levels (Bandura, 1999). The north Korean issue affected moral disengagement in collective level. How the authoritarian regime threat people in violence behavior. As a state, North Korean government should be good moral agency to their society, but in reality it never happened. According to Bandura, moral agency has dual aspects manifested in both the power to refrain from (Bandura (b), 2002). Inhibitive and Proactive action. To simplify, inhibitive action when moral agency behave inhumanity and proactive action when moral agency behave humanity.

The Pyong Yang policy seems more inhibitive moral agency than proactive. They use Juche Ideology to justify their moral standard. However, violent behavior in North Korea redefined as an act of righteousness, or even a necessity for reaching desirable goals from government (Jackson and Sparr, 2005 : 2). Psychological behavior of this regime affected many victims in national and international level.

There are a few mechanisms in moral disengagement, they are moral justification, euphemistic labeling, advantageous comparison, displacement of responsibility, diffusion of responsibility, disregard or distortion of consequences, and dehumanization (Bandura, 1999). According to that mechanism, violence in North Korea can analyze by 3 components of moral disengagement; first moral justification to justify that their threat to political violence based on Juche Ideology's goal; second Euphemistic labeling, they claim that they are not do violence. What the Government (GOD) to them about becomes good people; the third dehumanization is about thinking the violence not human and treat them like an animal.

\section{Moral justification}

Moral justification is about has own moral standard. We can be good or not. Because people can be good or cruel. In this case, North Korea using its moral standard (Juche) as a reasonable action in inhumanity. To protect political stability in his country, the government arbitrarily arrested people who were deemed to potentially threaten government authority, put them in torture camps, arbitrarily treated them like animals.

In prison, they are forced to work, including children and women. Pregnant women forced to have an abortion. The detainees were assigned to build infrastructure, carry out 
projects, and carry out activities and events in praise of Kim's ruling family and the Korean Labor Party (Human Rights Watch: 2019).

The prison camp is the most terrible in the world. Every witness admitted that they were forced to work from 3.30 in the morning until evening without being given food. Many starved to death. Even those who are sick and die after returning from prison. Not only for prisoners in the country, but prison is also intended for foreign citizens who are considered threatening. One student from the United States said that he often experienced torture in prison. Tortured on an electric chair. Beaten up. This regime has low moral standards according to protect society. North Korean Government has own self-standard about Moral. Build self-sanction and used moral justification to protect their standard of moral disengagement.

\section{Euphemistic Labelling}

Euphemistic labeling is about using good words to say something worse or punishment. It probably more like brainwashed. They did not think that they are oppressed. Something interesting, when they believe they are living in the center of the world and the Kim family is their God. They born to be the God slave (Women in The World: 2015). Then they do not understand what kind of condition they have because this country is close. They even did not have a shower, internet, or any kind of technology.

North Korean government doctrine them as people who live in the center of the world. Their live is to slave the God (North Korean Leader) (Women in the world: 2015). The get a good place and became a good kid of God. Even they do not that they are impressed.

\section{Dehumanization}

Dehumanization is about threatening people inhumanity. They do not deserve good treatment because they are not human but animals. Many people in prison camp threaten like unhuman. They work all day long, don't get food, etc. North Korean government think that they are only god slave and since they defector from the government, they get punished.

\section{DISCUSSION}

\section{Effect of the violence}

According to the Juche ideology, North Korea became a democide. It means the murder of any person or people by a government, including genocide, politicide, and mass murder (Rummel, 1997). The high number of violence in North Korea cannot calculate 
approximately because of a limited resource. Nevertheless, citizens totals given a probable 710,000 to 3,549,000 people killed, or a mid-value of 1,663,000 (Rummel, 1997). Then, there are 31,827 North Koreans have defected and 72 percent of them were women (Yang: 2018). Although North Koreans resettling in South Korea seemed to be the easiest and obvious choice compared to resettling in other foreign countries, reality deemed different.

A very low human right standard in North Korea is the impact of moral disengagement by the government. According to the United Commission on Human Rights, North Korea cannot provide its self as a country to provide food, liberty, and political freedom. Since it has a dictatorship regime, but the main issue about famine is the worst. The 2018 Global Hunger Index classified the level of hunger as "serious" and "bordering on alarming", ranking the Democratic People's Republic of Korea 109 out of 119 ranked countries. The report cited the "troubling trend" of worsening hunger and undernutrition,39 with a score of 34 in 2018 -an increase from 28.2 in 2017, and the highest since 2000 (OHCR, 2019).

The other effect is less political freedom, since people who against the government will be a prosecution. Even the right for education or entertainment. That's why many people try to escape from this country and no one won't come back.

This moral disengagement also impacts on international threats. North Korea is terrorizing through nuclear testing. In 2017, the Democratic People's Republic of Korea (DPRK) fired 23 missiles during 16 tests and conducted a sixth nuclear test, raising tensions on the Korean peninsula to the highest level in decades (BBC, 2019)

As moral agency, country has responsibility to protect their society. However, every country has their preferences political ideology to believe. Some countries choose democracy, others may be use communist or authoritarian. Nevertheless, still the responsibility to protect humanitarian aspects are important. What happened in North Korea is one discourse that sometimes ideology can be affected violence to their society. There is nothing wrong with Juche's value. Self-resilience to be independent by their own. Unpopular ideology in the world. But, how country imply it may be wrong. Hundred thousand of victims, instability of East Asia region, and international terror. 


\section{The Possible Scenario in North Korea Reconciliation Process International intervention in North Korea}

As a neighbor country of North Korea, South Korea takes part in the responsibility for what happened in that country. Therefore, both of them are united in ancient history. There are some NGOs supports North Korean Defector. In July 2018, there are 31.827 refugees in South Korea and 65\% in women (Korea Hana Foundation, 2018)

In addition to trade intervention, South Korea as a neighboring country of North Korea and the same history enforces a policy called the "Sunshine Policy". This policy aims to open up more massive cooperation related to the economic humanitarian assistance program in North Korea. This Policy Sunshine Policy was issued by the government of Kim Dae Jung (1998). The Sunshine policy was based on three following principles: a) No armed provocation by the North will be tolerated; b) The South will not attempt to absorb the North in any way; c) The South actively seeks cooperation (Min, 2017). This policy has had a positive impact on increasing economic interaction between North and South Korea. More specifically this policy also dampened the high defense budget of South Korea when there was a North Korean military provocation. On the other hand, this policy also received criticism as if North Korea played stick and carrot game.

Even though, the US and China as one of the world's powers are currently trying to face North Korea on the negotiating table. East Asia Summit is one form of initiation to conduct nuclear interventions in North Korea. Negotiations conducted between the countries of Southeast Asia, East Asia, plus the United States and China to discuss cooperation in the Asian region. However, this table negotiation does not appear to be effective enough to reduce the "delinquency" of North Korea (Kim, 2017)

Peace intervention can be done by providing economic sanctions. In February 2017, the Chinese government imposed sanctions on coal imports from North Korea so that North Korea would return to the negotiating table regarding its nuclear energy (Kim, 2017). however, this method is less effective and instead poses a threat that North Korea will play again with its nuclear development.

The international public has a quite dilemmatic position facing northern Korea. On the one hand, international sanctions have been made but on the other hand, half of the population of North Korea is experiencing a humanitarian disaster. Pyongyang does not want to denuclearize. But, in 2018 Pyongyang and Washington DC has signed agreement about 
committing to work together to "build a lasting and stable peace regime on the Korean Peninsula" (VOA, 2018).

To sum up, there is no direct military intervention in North Korea because of authoritarian regime still dominant, there is no revolution from the grass root level, and nuclear propaganda that affected international fear. Peace intervention in North Korea using more soft power than hard power. Economic sanction, foreign aid, and agreement are the way to achieve peace building process in North Korea. A few countries that highly involve in this issue are US, Russia, South Korea, and Japan.

\section{Peace and Conflict Approach}

During the last 2 decades, many countries try to approach reconciliation in the North Korean conflict. South Korea is one of the most proactive actors. As the neighboring country, The South will be most affected by anything happened in the North. North and South Korea has a similar historical background since the era of three dynasties. Then, South Korea has an important role to approach North Korea. Even South Korea has not strong enough power compared with China or the US, but the possibility to encourage other countries to join this program is high.

In 1998 until 2008, South Korea published Sunshine Policy towards North Korea under Kim Dae-Jung and Rho Moo-Hyun leadership. This policy was inspired by the successful normalization of West and East Germany. By the character of the Korean peninsula, this policy separates the economy and politics. The three main principles are a) Not to tolerate armed provocation from North Korea, b) South Korea will not try to absorb North Korea in any way, and c) South Korea is actively seeking cooperation. In 2000, the president of KIM won the peace prize because of this policy(Min, 2017). Based on this issue, the best way to approach North Korea is by soft power.

The most challenge in the reconciliation process of North Korea is Political Will from the government. Since the regime unshakeable, it is hard for other countries to get involved. Therefore, the consequence of military invasion is high risk. It will affect more victims because of nuclear power.

There are two recommendations toward South Korea in the reconciliation process of the North Korean conflict:

Humanitarian Aid based on Psychology of Peace Intervention 
Until 2018, there are 31,827 North Koreans have defected and 72 per cent of them were women in South Korea (Yang, 2018). Most of them experience very difficult life in North Korea since they came to South Korea, there is no guarantee to get a better life. Then, the North Korean government should focus on Trauma healing intervention (Min, 2017).

Each defector from North Korea chooses to die than sent back to that country. It is indicated that worse experience in North Korea affected such a huge trauma. This kind of trauma can be transferred to the next generation. It possible to affected intergenerational trauma since many of them are women, trauma can be transfer during pregnancy.

According to the issue of Defector trauma, South Korea has an important role to help them maintenance trauma and get resilience. Some of the programs can be implemented by the South Korean Government about trauma healing for defector are:

- Sens of safety: Since they arrive in South Korea in the refugee camp, the government should interevent to make them feel safe.

- Calming: To arrive South Korea, is not an easy way. People should be shocked. If we remember the story from North Korea Defector in the US, her father passed away in the middle of the journey to the south.

- Sens of self- and community efficacy. In the refugee camp, it is important to make feel efficacy. Encourage them to join in some social activity, making product etc. is good wat to push away trauma.

- Connectedness: In the refugee camp, feeling connectedness with other society is important. Even it's hard for the first time. It is important to do that.

- Hope: Motivation session is important to raise hope for them. For a better life.

Give them a place, and accept them. As we know, South Korea faces an ageing society issue. It is important to accept North Korean and give them an opportunity in South Economy. The similarity of language, ethnic, and historical background are important factors to accept them in the labor market.

\section{Sunshine Policy II}

Lesson learned from the previous sunshine Policy in 1998-2008, it is important to think about the continues of this policy. This policy focuses on economic development and separate political aspects. Sunshine policy has initiated the Korean Peninsula reunification as the facto (Larasati, 2013). Even North and South not reunited as the Jure, it will be well initiated to be reunited as de facto. Some of the successfulness of sunshine policy according 
to the issue when most Economic Aid toward North Korea initiated by People in Jeju's Island. They also try to build the brotherhood between North and south in social and economic aspects.

In 2018, North and South Korea became one group in the Asian Games (multisport competition). The unified Korean 500m women's dragon boating team has won a gold medal in the Asian Games - the first time the north and south have combined to win the top prize. This is the big step for the Korean peninsula to start management conflict between them. According to the successful of Asian Games 2018, it good to start the Sunshine Policy II. There are more chance of South Korea to approach North Korea from Cultural and Economic aspects. The II model of The Sunshine Policy should be more focus on seeking trust of North Korea to get involve in Social and Cultural cooperation.

\section{Diplomatic Talk}

Diplomatic talk is one of best option towards North Korean issue. It can be address bilateral diplomatic or multilateral diplomatic. Based on the South Korea position, it is quite hard to propose diplomatic talks. They need another actor as mediator. Then, the most effective chance is flowing the issue to the multilateral organization.

South Korea is a member of East Asia Summit, the Indo-Pacific's premier forum for strategic dialogue. The members are ASEAN countries (10 members) along with Australia, China, India, Japan, New Zealand, the Republic of Korea, the United States and Russia. These 18 members represent 54\% of the world's population and account for around 58\% of global GDP worth an estimated US\$49.4 trillion (Australia Government, 2018). North Korea can use the diplomatic talks in this meeting to persuade other members such as China, US, and Russia as Major Power to encourage North Korea about the nuclear weapon.

Address the north Korean issue in the wider organizations is important to seek international support about the conflict. The East Asia summit meeting can push Pyong yang to denuclearization their own. Even, the member of the East Asia summit can push North Korea with Trade Ban or Humanitarian Aid banned.

\section{CONCLUSION}

Psychology of peace and conflict examines how Juche Ideology exists in North Korea and affected to the violence. Regarding the authoritarian regime, this Ideology as a tool to justify their national policy. Juche's value is verified their independence and pride to the global world. Unfortunately, it affected human security for national and global society. This 
situation cannot be resolve by military interventions. The conflict is complex. Then, the reconciliation should be the focus on violence, be calm and not an aggressive policy because it will be adding more violence and maintenance balance security in the East Asia Region.

\section{REFERENCES}

Australian Government. 2018. East Asia Summit. https://dfat.gov.au/internationalrelations/regional-architecture/eas/Pages/east-asia-summit-eas.aspx [14/02/2020].

Bandura (b), Albert. 2002. Selective Moral Disengagement in the Exercise of Moral Agency. Journal of Moral Education, Vol. 31, No. 2, 2002. Stanford University USA. https://web.stanford.edu/ kcarmel/CC_BehavChange_Course/readings/Additional\% 20Resources/Bandura/bandura_moraldisengagement.pdf

Bandura, Albert. (n.d.), Moral Disengagement In The Perpetration Of Inhumanities, Stanford University. https://www.uky.edu/ eushe2/Bandura/Bandura1999PSPR.pdf.

Bandura, Albert. 1999. Moral disengagement in the perpetration of inhumanities. Personality and Social Psychology Review. [Special Issue on Evil and Violence], 3, 193-209.

BBC. 2019. North Korea's missile and nuclear programme. BBC Asia ( October 2019. https://www.bbc.com/news/world-asia-41174689

DW News. (2019). UN : 10 Million face Hunger in North Korea, published May $3^{\text {rd }}$, 2019. https://www.dw.com/en/un-10-million-face-hunger-in-north-korea/av-48595072

Human Right Watch. 2019. North Korea. https://www.hrw.org/world-report/2019/countrychapters/north-korea

Institute of Economic and Peace. (2019). Global Peace Index 2019. http://visionofhumanity.org/app/uploads/2019/06/GPI-2019-Briefingweb-2.pdf

Jackson, Lydia Eckstein \& Jennifer L. Sparr. 2005. Introducing a new scale for the measurement of moral disengagement in peace and conflict research. Conflict \& communication online, Vol. 4, No. 2, 2005. http://www.cco.regeneronline.de/2005_2/pdf_2005-2/es.pdf

Kim, Hyung-Kyung et.al. (2017). Peace and Prosperity on The Korean Peninsula : getting China to The Table. Belfer Science and International Affair, Harvard Kennedy School.

Korea Hana Foundation. (2019). Annual Number of North Korean Refugees Entering South Korea. https://northkoreanrefugee.org/eng/info_on_nkrefugee/data_stastics.jsp

Korea-dpr. (n.d.). Juche Ideology. https://www.korea-dpr.com/juche_ideology.html

Larasati, Sasmithaningtyas P. and Meidi Koesnandi. 2013. The Dynamics implementation Sunshine Policy by South Korea towards Korea Reunification 1998-2003. http://lib.ui.ac.id/naskahringkas/2015-09/S47268-

Sasmithaningtyas\%20Prihasti\%20Laraswari

Lee Grace, (2003), The Political Philosophy of Juche, Stanford Journal of East Asia Affair, Vol 3: No. 1, Spring 2003. https://s3.amazonaws.com/berkleycenter/030101LeePoliticalPhilosophyJuche.pdf

Min, Jesse. (2017). The Sunshine Policy of South Korea. Stanford University. http://large.stanford.edu/courses/2017/ph241/min2/

Min, Jesse. 2017. The Sun Shine Policy of South Korea. http://large.stanford.edu/courses/2017/ph241/min2/ [13/02/2020]

OHCR. 2019. The price is rights: The violation of the right to an adequate standard of living in the Democratic People's Republic of Korea.United Nation Human Right 


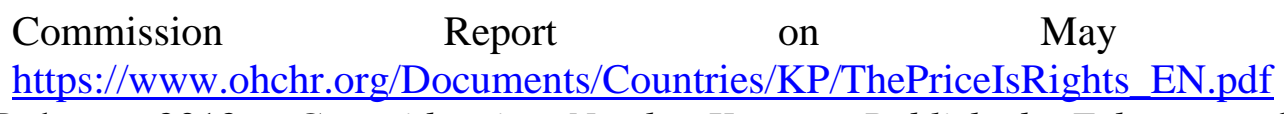

2019.

Park, Robert. 2012. Genocide in North Korea. Published February 6, 2012. https://worldpolicy.org/2012/02/06/genocide-in-north-korea/

Park, Yeon-Mi. (2019). What I learned about freedom after escaping North Korea|Yeonmi Park. TED Talk. https://www.youtube.com/watch?v=mLzTo-y8Ef0.

Przybyła, Katarzyna A.. 2020. Trauma Healing and Resilience. Course material of Psychology of Peace and Conflict Studies. Warsawa: Collegium Civitas.

Rouse MAJ Ed and SGM Herbert A. Friedman.2019. North and South Korean Psychological Warfare. http://www.psywarrior.com/korea.html.

Rummel R.J.. 1997. Genocide and Mass Murder Since 1900. Center for National Security Law, School of Law, University of Virginia and Transaction Publishers, Rutgers University.

Staub, Ervin. 2001. Genocide and Mass Killing : Their roots and prevention. In Christie, D. J., Wagner, R. V., \& Winter, D. A. (Eds.). (2001). Peace, Conflict, and Vio-lence: Peace Psychology for the 21st Century. Englewood Cliffs, New Jersey: PrenticeHall.

Vision of Humanity.(2018). The Cost of Violence in North Korea. http://visionofhumanity.org/north-korea/cost-violence-north-korea/

VOA. (2018). President Donald Trump and North Korean leader Kim Jong Un have ended their summit by signing a historic agreement. https://www.vox.com/2018/6/12/17452532/trump-kim-document-agreement-fulltext-denuclearization-read

Women in The World. 2015. Yeonmi Park: My escape from North Korea. Published 15 October 2015. https://www.youtube.com/watch?v=h-hS8A85_RE

Yang, Jea. 2018. Struggles of resettlement: North Koreans in South Korea. Psychology International

September

2018

eds. https://www.apa.org/international/pi/2018/09/north-koreans-resettlement 